\title{
TENDER BONDS: DETERMINANTS, PROCEDURES AND IMPLICATIONS FOR CREDIT GUARANTEE FUNDS
}

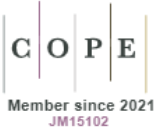

https://doi.org/10.18778/2391-6478.2.30.08

\section{Dariusz Sobolewski*}

\begin{abstract}
The purpose of the article is to outline a new procedure that will enable economic operators to increase their access to tender bonds provided by funds for credit guarantees which are among the non-monetary forms of submitting a deposit in public procurement procedure.

Methodology used to present the topic and to achieve the goal of the article is mainly based on the expertise and professional experience of the author.

Results of the research outline that despite being properly established in Polish law, tender bonds have as yet been scarcely applied by economic operators requesting to participate in public contract award procedures. Moreover, the majority of credit guarantee funds focus on providing this type of sureties, with the consequence being an increasingly declining share of credit sureties and changes in these funds' business profile. In order to continue this increase in tender bond sale, credit guarantee funds need to modify their existing procedures so as to make this type of security more popular among economic operators.
\end{abstract}

Keywords: credit guarantee fund, suretyship, tender bond, public procurement, micro, small and medium-sized enterprises.

JEL Class: D250, G230, G320.

\footnotetext{
* Ph.D., Wydział Finansów i Zarządzania, Wyższa Szkoła Bankowa we Wrocławiu; https://orcid.org/0000-0002-1774-1871.
} 


\section{INTRODUCTION}

Participation in public procurement procedures is an essential determinant of the development of many micro, small and medium-sized enterprises. For an economic operator to be effective in their bidding on public contracts, this may entail having to submit a deposit, as a security ensuring that a public works agreement (contract) will be concluded with the contracting authority. The data base of public contracts is available primarily in the Public Procurement Bulletin run by the Public Procurement Agency ${ }^{1}$.

The tender security may be perceived as a financial barrier whose purpose is to ensure participation of only those economic operators which are sincerely interested in concluding the contract and performing the relevant work. The Act of 29 January, 2004 - Public Procurement Law (OJ, 2018, item 1986), hereinafter referred to as ,the PPL Act”, regulates the institution of deposit, as an optional or mandatory element involved in the public procurement procedure. It should be underlined that pursuant to Article 11 of the PPL Act, if the contracting authority is above the respective threshold amounts, tender security is mandatory. The public procurement practice shows that using deposits is a very common practice among contracting bodies, as this instrument proves to be very effective in preventing, and ultimately sanctioning the economic operators' failure to fulfil the specific obligations imposed on them under the procedures for awarding a public contract. The PPL Act allows for a monetary form in which to pay a deposit (a specific amount of cash paid to a bank account is indicated by the contracting authority) and non-monetary form (by establishing a specific right to the benefit of the contracting authority), which also includes a surety issued by credit guarantee funds.

Since 2015 there has been a steady increase in the credit guarantee funds' operations regarding the provision of sureties which act as tender bonds. Curiously, their characteristic feature is lower risk despite the fact that tender bonds are unconditional and have to be paid by the funds virtually upon the contracting authority's request. Still, the evaluation of economic operators applying for a surety (a tender bond) is not that much different from the evaluation conducted in the procedure for granting loan sureties. This approach makes some economic operators abandon their intention to apply for tender bonds because the evaluation process is too extensive. At the same time, the credit guarantee funds are very keen on granting this type of sureties because they considerably improve the quality of the funds' suretyship portfolios. As a result, we are observiing a gradual replacement of the traditional credit sureties with tender bonds.

${ }^{1}$ The official publication of public contracts issued in electronic form and run by Public Procurement Agency, avaiable on internet portal www.uzp.gov.pl. 


\section{THE RATIONALE FOR RAISING THE ISSUE}

The specialist literature tends to concentrate on the formal and legal aspects relating to the non-monetary forms of tender security applied in public procurement procedures, including tender bonds. Apart from describing the forms for securing public procurement procedures available to economic operators (Panasiuk, 2013; Pieróg, 2019), the authors also identify the risks involved in the non-monetary forms of the deposit (Puchacz, 2010). The literature features a broad discussion of the possible different interpretations of the PPL provisions as regards the requirement of returning the deposit or a circumstance where it is retained in the context of public procurement electronisation (Packo, 2016). With respect to the non-monetary forms used in securing tender procedures, the literature describes predominantly the substance, characteristic features and application of the insurance guarantee-based deposit (Mazurek, 2018: 20-23; Pieprzyca 2018: 13-17).

One ought to emphasise that no detailed economic analysis exists that would also cover the implications arising for credit guarantee funds from refocusing their current functions in the economy. There is a gap in the research concerned with the functioning of credit guarantee funds in Poland because of the absence of an analysis which would study the effect of the tender bond offer on the activity and development of micro, small and medium-sized enterprises.

Using non-monetary deposits in the form of tender bonds provided by a credit guarantee fund may have a significant impact on the financial situation of micro, small and medium-sized enterprises, in particular in terms of their liquidity and solvency. Hence, the growing need to disseminate this form of securing public tenders, which may potentially be advantageous to economic operators as well as credit guarantees funds.

Considering that tender bonds account for an ever growing share in the funds' portfolios, it is necessary to endeavour to outline a procedure optimizing the use of these bonds by economic operators participating in tenders. The procedures currently in place for evaluating economic operators which apply for tender bonds encompass financial as well as qualitative elements (KGP).

For the scale of tender bonds used by economic operators to expand, it is necessary that the existing processes relating to the assessment of the applications be adapted to economic operators' needs. What is meant here, in the first place, is the need to shorten the procedures in such a way as to make the waiting period correspond closely to that needed to make a bank transfer. This should result in tender bonds becoming a tool easily available to economic operators which would therefore no longer need to commit their liquid funds. Furthermore, this would also have an even greater impact on the development of the credit guarantee funds and increase in their activity. The paper endeavours to outline a new procedure 
which would enable economic operators to have a greater access to this form of tender security. The procedure may also prove a useful solution for credit guarantee funds. In order to attain this objective, the expert method was largely deployed.

\section{DEPOSIT AS A NON-MONETARY FORM OF SECURING A TENDER PROCEDURE}

The provisions of the PPL Act specify, in particular, the forms of deposit payment, the time limit prescribed for it, and its maximum amount. The regulations laid down in the PPL Act also stipulate the circumstances under which a deposit may be retained or returned, along with the consequences facing economic operators failing to submit the set amount within the deadline laid down in the Act. However, it should be noted that the PPL Act does not provide a definition of the deposit term itself, merely referring (in line with the content of Article 14) to Article 704 of the Act of 23 April 1964, the Civil Code (OJ, 2018, items 1025 and 1104)22.

In the light of the provisions of the PPL Act, under the procedures for awarding public contracts, the deposit to be paid may be either in the form of a specific amount of cash paid to the contracting authority or by establishing security for this payment in accordance with strictly specified forms. Pursuant to Article 45 para. 1 of the PPL Act, apart from being paid as cash or bank sureties or guarantees of collective saving-loan fund, the deposit under these procedures may be paid, in particular, as bank guarantees and insurance guarantees, as well as sureties given by entities referred to in Article $6 \mathrm{~b}$ para. 5 item 2 of the Act of 9 November 2000 on Establishment of Polish Agency for Enterprise Development (OJ, 2016, items 359 and 2260 and OJ 2017, item 1089) i.e. credit guarantee funds. Table 1 shows the most important non-monetary forms of deposit. The selection of a specific form in which to pay the deposit is an independent decision made by an economic operator based on the analysis of its own needs, preferences and capabilities, as well as the tender terms. While defining the requirements included

${ }^{2}$ Pursuant to Article $704 \S 1$ and 2 of the Civil Code, under an auction or tender procedure, one may stipulate that auction or tender participants should pay to the relevant organizer a specific fee, or provide appropriate security (tender bond) for this payment, on pain of being excluded from participation. Should the auction participant or tenderer, despite the fact that their offer has been selected, fail to conclude the relevant agreement (whose validity relies on fulfilling specific requirements provided for in the agreement), the organizer of the auction or tender may retain the fee collected or pursue the right to realize the security. In all other cases, the tender security paid is to be returned, while the security expires. Should the auction or tender organizer fail to conclude the agreement, the participant whose offer has been selected may demand to be paid a double tender security amount or to be compensated for the damage suffered. The tender bond structure as adopted in the Civil Code renders it an integral component of a tender relationship and auction, and for public procurement it is also an integral component in the contract award procedures which those entering them accept. 
in the specification of essential terms of the contract, the contracting authority may not constrain economic operators in their choice of the deposit form ${ }^{3}$.

If the contracting authority reserves the right to deposit, the provisions of the PPL Act require that the deposit, in the public procurement procedure, be not only established but also really paid. The implication arising therefrom is that this act may fall into the category of real acts-in-law which for their effectiveness require, beside the submission of declaration of intent, that a real action be undertaken to transfer actual control over the thing (with respect to the deposit payment, we are facing here a situation in which a specific amount of monetary resources is paid to the contracting authority's bank account or the handing over of a document establishing a non-monetary security).

In the public procurement procedure, the essential purpose of a deposit is to secure tenders submitted by economic operators. The assumption is that what characterizes the deposit which has been made correctly (in other than cash form, e.g. a tender bond by a credit guarantee fund) is that it provides a real assurance that the set amount can be executed, and as such it secures properly the contracting authority's interest. As regards the content of the statement granting a surety, the obligation on the part of the surety should be unconditional, abstract, i.e. autonomous, with the tender bond amount having to be paid at the beneficiary's (contracting authority) first demand, as highlighted in the case law of the National Chamber of Appeal and doctrine in force. It should further be emphasised that the economic operator has a direct say in the content of the tender bond; in the application, the economic operator orders, for a fee, the credit guarantee fund to provide a tender bond to the benefit of the contracting authority, which means that it is in the economic operator's interest, also being its obligation, to make sure that the tender bond purpose is properly defined, i.e. it secures the payment of the deposit properly and to a sufficient degree ${ }^{4}$.

The assessment of whether the deposit in the form of a tender bond has been made correctly is crucial, in particular because the provisions of the PPL Act do not define tools that would allow to submit the deposit in a faulty manner to be validated. Nor is it possible for the contracting authority to explain any doubts as to the tender bond content. The document handed in by the economic operator stating that it has been granted the tender bond (as a rule, this is a one-page document of tender bond provision issued by the credit guarantee fund) is not included in the documentation relating to the procedure for awarding a public

${ }^{3}$ Cf. Article 36 para. 1 item 8 of the Act of 29 January 2004 - Public Procurement Law (OJ of 2018, item 1986).

${ }^{4}$ Cf. Judgment of the National Appeals Chamber of 14 Nov 2016, in case KIO 2055/16. Although the judgment refers to a guarantee, its reasoning may also lend itself to a tender bond issued by a credit guarantee fund. 
contract $^{5}$. Hence, there exists no possibility for economic operators to rectify errors that may appear in the regular process of lodging a tender security, under Article 26 para. 3 of the PPL Act ${ }^{6}$.

Table 1. Non-monetary forms of deposit in the public procurement procedure

\begin{tabular}{|c|c|c|}
\hline No. & $\begin{array}{l}\text { Deposit } \\
\text { form }\end{array}$ & Description \\
\hline 1. & $\begin{array}{l}\text { Bank } \\
\text { guarantee }\end{array}$ & $\begin{array}{l}\text { In return of a commission, the bank acts as a guarantor for the fulfilment of specific } \\
\text { obligations to the benefit of the beneficiary of the guarantee }{ }^{7} \text {. The bank guarantee } \\
\text { relationship consists of two elements: (1) the agreement between the bank and the } \\
\text { client (i.e. under the public procurement procedure - an economic operator bidding } \\
\text { on the public contract), which sets out the guarantee provision, its content and terms } \\
\text { (2) a written guarantee provision statement submitted to the beneficiary of the } \\
\text { guarantee (contracting authority) by the bank providing the guarantee. The } \\
\text { requirement of a written statement is of particular importance given that a deposit } \\
\text { paid in the form of payment security (guarantee) does not yet constitute the economic } \\
\text { operator's declaration of intent, being merely an act of factually submitting } \\
\text { a document containing the bank's statement addressed to the contracting body. The } \\
\text { deposit payment in the form of a bank guarantee should involve handing in the } \\
\text { guarantee document in the same form as it was issued by the bank - guarantor, i.e. as } \\
\text { an original document. }\end{array}$ \\
\hline 2. & $\begin{array}{l}\text { Insurance } \\
\text { guarantee }\end{array}$ & $\begin{array}{l}\text { In return for a commission (premium), the insurer takes over the role of a guarantor } \\
\text { based on the relevant agreement, which ensures that the specific obligations towards } \\
\text { the beneficiary of the guarantee will be } \text { met }^{9} \text {. Under public procurement, a deposit } \\
\text { based on insurance guarantee secures the relationship under the public procurement } \\
\text { procedure between the beneficiary of the guarantee and the party applying for the } \\
\text { guarantee established by having submitted a bid in the public procurement procedure. } \\
\text { Analogously to the bank's obligation arising from the bank guarantee, the insurer's } \\
\text { obligation, is a monetary obligation involving payment of the guarantee amount in }\end{array}$ \\
\hline
\end{tabular}

${ }^{5}$ Cf. Ordinance of the Minister of Development of 26 July 2016 on the types of documents that may be required by a contracting authority from an economic operator in a public procurement procedure (OJ, 2016, item 1126).

${ }^{6}$ Nor do the documents confirming the tender bond provision form part of the tender, understood as the economic operator's declaration of intent, including all other documents and information rendering this declaration more specific, regarding the scope and manner of the obligation performance, it being the subject matter of the contract.

${ }^{7}$ Pursuant to Article 5 para. 1 item 4 of the Banking Act of 29 August 1997 (OJ, 2017, item 1876, as amended) issuing and confirming a bank guarantee falls under the term "banking operations", while Article 81 of the Banking Act defines a bank guarantee.

${ }^{8}$ The bank and the client are bound by a mandate contract within the meaning of Article 743 of the Civil Code (OJ, 2018, items 1025 and 1104)

${ }^{9}$ According to Article 4 para. 7 item 1 of the Act of 11 September 2015 on Insurance and Reassurance (consolidated text OJ, 20018, item 999), concluding insurance guarantee agreements is an insurance activity, which means that the operation of the entity granting this type of guarantee is subject to the provisions of the above mentioned Act. The provisions of the Act on Insurance and Reassurance do not define the concept of an insurance guarantee, confining itself actually to simply including guarantees in the list of insurance activities. 


\begin{tabular}{|c|c|c|}
\hline & & $\begin{array}{l}\text { the case of a guaranteed outcome }{ }^{10} \text {. The insurance institution grants a guarantee based } \\
\text { on the economic operator's order, which sets in motion the action involving the } \\
\text { submission of a declaration of intent to provide the guarantee to the beneficiary of } \\
\text { said guarantee by the insurance institution. In line with the specific nature of public } \\
\text { procurement and the rules on conducting procedures for awarding public contracts, } \\
\text { the insurance guarantee acting as a security for the economic operator's bid requires } \\
\text { a material form (a letter of guarantee, insurance coverage). }\end{array}$ \\
\hline 3. & $\begin{array}{l}\text { Surety by } \\
\text { a credit } \\
\text { guarantee } \\
\text { fund }^{11}\end{array}$ & $\begin{array}{l}\text { Pursuant to Article } 6 \mathrm{~b} \text { para. } 5 \text { item } 2 \text { of the Act of } 9 \text { November } 2000 \text { on Establishment } \\
\text { of Polish Agency for Enterprise Development (OJ, } 2007 \text { No } 42 \text {, item } 275 \text { ), credit } \\
\text { guarantee funds are empowered to provide tender bonds, as set out in Article } 45 \text { para. } \\
6 \text { item } 5 \text { and Article } 148 \text { para. } 1 \text { item } 5 \text { of the PPL Act. Moreover, the institution of } \\
\text { bank suretyship itself is governed by the provisions of the Civil Code (Article } 876 \text { and } \\
\text { next) }{ }^{12} \text {, according to which under a suretyship contract, the surety commits to the } \\
\text { creditor to perform an obligation if the debtor fails to do so. The surety's declaration } \\
\text { should be made in writing otherwise it is not valid. What should also be underlined is } \\
\text { that it is imperative for tender bonds provided for the purpose of a public procurement } \\
\text { procedure to indicate the validity term. This clause is critical because a surety without } \\
\text { a time limit for a future debt may be revoked at any time before the debt arises, in the } \\
\text { light of Article } 878 \text { para. } 2 \text { of the Civil Code. The implication of this is that such surety } \\
\text { fails to fulfil the purpose of the deposit, which is to secure the economic operator's } \\
\text { tender during the time between the tender submission deadline and the moment of } \\
\text { choosing the most advantageous tender (this being the minimum time limit), and the } \\
\text { agreement conclusion date for public contract performance (the maximum time limit). }\end{array}$ \\
\hline
\end{tabular}

Source: the author's own study.

As already shown, deposit in the form of a tender bond is a legally admissible possibility of securing the tender procedure. It may therefore be appropriate to carry out an in-depth analysis of the scale on which this instrument has been deployed by entrepreneurs.

\section{THE USE OF TENDER BONDS BY ECONOMIC OPERATORS ${ }^{13}$}

As of 2014 credit guarantee funds have been consistently increasing their activity, mainly on account of tender bonds. This has led to a gradual change in the profile of these funds, which are limiting their provision of traditional sureties for bank credits and loans (Gajewski et al., 2019). On the one hand, this has been brought about by the banks' reduced demand for this form of security, while on the other hand, it is

${ }^{10}$ Cf. Article 46 para. 4a and 5 item 8 of the Act of 29 Jan 2004 - Public Procurement Law (OJ, 2018, item 1986).

${ }^{11}$ The Act of Public Procurement Law also allows for a tender security to be made in the form of bank sureties or guarantees of collective saving-loan fund (Article 45 para. 6 item 2).

12 Both Article 84 of the Banking Act, as well s Article 6b para. 8 of the Act of Polish Establishing Agency for Enterprise Development refer one to the relevant provisions of the Civil Code governing the suretyship institution.

${ }^{13}$ The data presented in point 3 come from a report by Gajewski et al., 2019 and from reports on the situation of credit guarantee funds in Poland over 2004-2017 published by the National Association of Guarantee Funds. 
a strategy pursed by the credit guarantee funds which, having spotted a chance for development in the area of tender bonds, have been focusing on selling them as an alternative form of security in the procedures for awarding public contracts.

Moreover, considering that tender bonds show a low risk of default we are also seeing a slow improvement in the portfolio quality of sureties provided by credit guarantee funds. This is further linked to the downward trend that has been seen over the last five years in the value of capital that the credit guarantee funds have at their disposal. In 2018 the capital value of 40 active guarantee funds amounted to PLN 986 million.

The increase in the tender bond activity, both in terms of the number of transactions and their value, is largely attributable to the funds having adapted to the permanent presence of de minimis guarantee as a competitive offer, as well as other portfolio products offered by Bank Gospodarstwa Krajowego (a state development bank) through banks ${ }^{14}$. This growing activity has been further fostered by launching mass provision of tender bonds whose share saw an increase from close to zero to a very high level in 2018. Chart 1 presents the breakdown of sureties sale according to purpose.



Chart 1. Breakdown of the sureties sale according to purpose [value in mPLN; share of tender bonds' sale in \%]

Source: self-reported data based on Gajewski et al., 2019.

${ }^{14}$ It needs to be noted that under the aid scheme implemented by Bank Gospodarstwa Krajowego, the maximum level of de minimis guarantee will increase up to $80 \%$ of the credit amount (the prior terms of the de minimis guarantee had this level limited to $60 \%$ ), with the period of working capital guarantee being also extended. This is likely to lead to the banks' lesser demand for sureties offered by credit guarantee funds for guarantees of up to $20 \%$ of the credit value, which represented an additional collateral for the de minimis guarantee (the maximum level of credit collateral using guarantees was not to exceed $80 \%$ of the credit amount). 
As Table 2 shows, in terms of the number of agreements concluded, tender bonds are already predominant and this situation is expected to continue over the next years.

Table 2. Sureties granted in 2018 according to purpose

\begin{tabular}{|r|l|r|r|r|}
\hline No. & \multicolumn{1}{|c|}{ Financing purpose } & \multicolumn{1}{c|}{ Number } & \multicolumn{1}{c|}{$\begin{array}{c}\text { Value } \\
{[\mathrm{k} / \mathrm{PLN}]}\end{array}$} & $\begin{array}{c}\text { Average value } \\
{[\mathrm{k} / \mathrm{PLN}]}\end{array}$ \\
\hline 1. & Investment & 821 & 165055 & 201 \\
\hline 2. & Working capital & 229 & 441211 & 197,9 \\
\hline 3. & Leasing & 52 & 18847 & 362,4 \\
\hline 4. & Tender bonds & 5478 & 382695 & 69,9 \\
\hline 5. & Performance bonds & 477 & 46431 & 97,3 \\
\hline 6. & Other & 539 & 17230 & 32 \\
\hline & Total & 9596 & 1071469 & 111,7 \\
\hline
\end{tabular}

Source: Gajewski et al., 2019: 24.

In order to illustrate the substantial share of tender bonds in the sale of sureties in 2018, the charts present the composition of sureties granted in 2018 according to their purpose - volume of sureties (Chart 1) and value of sureties (Chart 2). Regarding the volume of sureties by financing purpose, tender bonds accounted for as many as $57 \%$ of sureties in total. As for their value share, they made up 36\% of all sureties granted in 2018 , thus being second only to sureties securing working capital loans, predominantly bank overdrafts.

In terms of the value, the biggest share is made up of sureties made to the benefit of banks (54\%), including primarily bonds and sureties for bank guarantees. The number of sureties granted in 2018 which centre around entities other than banks stood at as many as $67 \%$. The possible conclusion is that this characteristic of the credit guarantee funds' operations will continue into the future, especially considering that the value of tender bonds on the public procurement market will see a continuous increase ${ }^{15}$.

With regard to the operations conducted by individual credit guarantee funds, Fundusz Rozwoju i Promocji Województwa Wielkopolskiego S.A (Fund for Development and Promotion of Greater Poland Voivodship JSC) based in Poznań deserves a note. In 2018 this fund provided the highest total amount of sureties (around PLN 185 million), with tender bonds accounting for as as many as 80\% (PLN 148 million). Interestingly, POLFUND Fundusz Poręczeń Kredytowych S.A., a credit guarantee fund, based in Szczecin granted sureties worth of PLN 122 million, with sureties given to banks and leasing companies accounting for $100 \%$ (the fund does not issue tender bonds). Furthermore, it is worth stressing

${ }^{15}$ Estimated value of tender bonds will be equal to PLN 5,5 billion in 2025 - an analysis conducted by a consulting firm, Deloitte (2019). 
that the market of credit guarantee funds has seen entities emerging which grant exclusively tender bonds (e.g. Biłgorajska Agencja Rozwoju Regionalnego S.A.).

The data presented show clearly that as a financial instrument capable of replacing deposits paid in cash in the public procurement procedures, tender bonds are starting to be increasingly prevalent in the funds' portfolios. This leads to the role of the funds being redefined, as they have been established with a view of increasing the availability of bank loans by rendering it possible to use a surety as a collateral for loan repayment.

The popularity enjoyed by tender bonds is also linked to their lower price compared to bank guarantees or insurance guarantees (on average, tender bonds are 3-5 times less expensive than guarantee instruments). Of further note is that unlike most of the other sureties offered by credit guarantee funds, tender bonds are sold directly to economic operators (end customers), which obviously required from the funds to modify their existing distribution channels (involvement of banks).

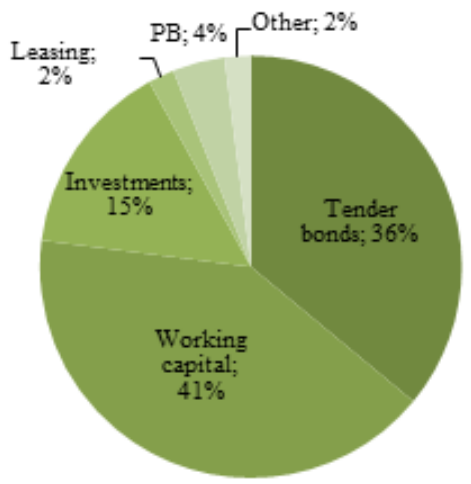

Chart 2. The composition of sureties providedin 2018 by purpose (volume)

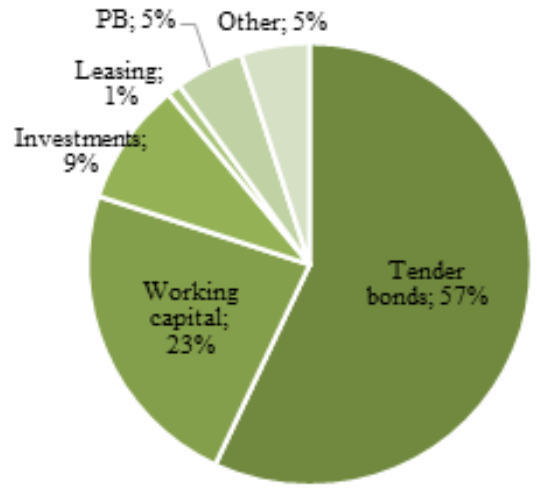

Chart 3. The composition of sureties provided in 2018 by purpose (value)

Source: Gajewski et al., 2019: 24.

This relatively new form which the credit guarantee funds use in their operations can also be looked at in the context of the continuous liquidity problems micro, small- and medium-sized companies face. These problems can further deteriorate as a result of an economic crisis. Replacing a cash-based deposit with a tender bond allows the cash (which would otherwise have to be paid to the contracting party's bank account as a deposit in the procedure for awarding public contracts) to stay in the economic operator's business. It seems 
that this may have a positive effect on the liquidity, or it will, at least, not lead to aggravating the problems with maintaining it.

The growing share of tender bonds witnessed in recent years, as well as that of performance bonds (to a much smaller degree) prompts the question as to the direction of development pursued by the credit guarantee funds over the next 3-5 years. To what extent will their activity focus on providing tender bonds and will these institutions continue to expand their offer in this area, thus rendering their products more available and attractive to entrepreneurs?

While attempting to answer this question, one should in the first place consider the possibility of putting forward a concept of the procedure for issuing tender bonds. Developing a new procedure will enable the process of applying for tender bonds to be simplified and quicker, which will contribute to their greater popularity among entrepreneurs.

\section{AN OUTLINE OF THE CONCEPT OF A PROCEDURE FOR TENDER BOND APPLICATION}

The procedure for awarding public contracts can proceed basically in the traditional (documents) or electronic form. However, it is to be expected that ultimately the electronic transmission of documents will become a rule, also for public contracts whose value is below the EU thresholds ${ }^{16}$. The available data show that in Poland micro, small and medium-sized enterprises are highly digitized and use remote distribution channels actively. The likely requirement of conducting all public procurement procedures through electronic means of communication will force the credit guarantee funds to modify their existing approach to servicing tender bonds, given that they tend to be provided in the traditional document form (a tender bond application, the relevant agreement, a statement of granting a tender bond are in the form of documents produced in the traditional form $)^{17}$. The presented concept of a procedure for tender bond application should be available particularly for micro and small-sized entrepreneurs (sole proprietorships and LLC companies). According to the information of the Polish Association of Credit Guarantee Funds, although the

${ }^{16}$ In contract award procedure commenced since 18 October 2018 and whose value equals or exceeds the EU thresholds (these issues are regulated by the European Commission regulations on threshold amounts, as referred to in the public procurement directives, including, among others, Directive 2014/24/EU of the European Parliament and the Council of 26 February 2014) the communication between the contracting authority and the economic operators is exclusively through electronic means of communication. See also the Article 10a para.1 of the Act of 29 January 2004 - Public Procurement Law (OJ, 2018, item 1986).

${ }^{17}$ Likewise, the amended Act of 11 September 2019 - Public Procurement Law (OJ , 2019, item 2019) which will be effective as of 1 January 2021, does not require all procedures for awarding a public contract to be conducted using electronic means of communication. 
majority of funds is well-prepared to provide tender bonds in the form of a document signed using an electronic qualified and certified signature (seal), this form for submitting declaration of intent to grant ${ }^{18}$ tender bonds does not yet replace the need to draft documents in the traditional form.

With a view to ensuring competitiveness of tender bonds, that is, to gain economic operators' interest in this form of lodging a tender security as an alternative to cash, the time needed for providing the tender bond should not differ that much from the time spent on making a bank transfer ${ }^{19}$. With this objective in mind, what would actually prove necessary is designing the entire process of selling tender bonds in an online system available to entrepreneurs over the Internet. Considering that simplicity and speed are of the essence in this process (from submitting a tender bond application to delivering the statement confirming that the tender bond has been granted), it can consist of the following three main stages:

1. economic operator decides to participate in the procedure for awarding a public contract (tender), but it does not want to pay the deposit in cash (bank transfer),

2. economic operator applies online for a tender bond,

3. if granted, economic operator receives the tender bond over the Internet or through a mail courier service.

Figure 1 presents the application process diagram in the system for tender bond online sale.

In the online process of issuing tender bonds, the evaluation of economic operators applying for tender bonds should encompass the following:

1. verification of the preliminary rules for economic operator qualification,

2. assessment of qualitative parameters characterizing economic operator.

Due to limited financial risk related to tender bonds (as opposed to credit sureties) an analysis and assessment of economic operator's financial situation may be reduced or skipped. If the credit risk analysis is provided, the online process would not be considered and perceived as attractive.

18 It should further be noted that, pursuant to Article 97 (2) of the Notary Public Law (consolidated text, OJ , 2019, item 540) it is allowed to obtain electronic certification of conformity of the transcript, extract or copy with the original (document), which bears the notary's advanced electronic signature verified by a valid qualified certificate. However, this option of a document transcript which may then be used in the public procurement procedure organized using electronic means of communication involves having to incur additional costs and to devote additional time by the economic operator to make said electronic transcript.

19 As the findings of an unpublished report on a quantitative study carried out in November 2019 and contracted out by a commercial bank show, for $72 \%$ of micro, small- and medium-sized economic operators, the maximum amount of a tender bond stands at PLN 20000,00 , while increasing the maximum amount to PLN 50 000,00 is sufficient for $88 \%$ of economic operators. Interestingly, for $65 \%$ of economic operators surveyed, the optimal time for a tender bond provision is one hour, while reducing this time to 15 minutes would satisfy $91 \%$ of respondents. 


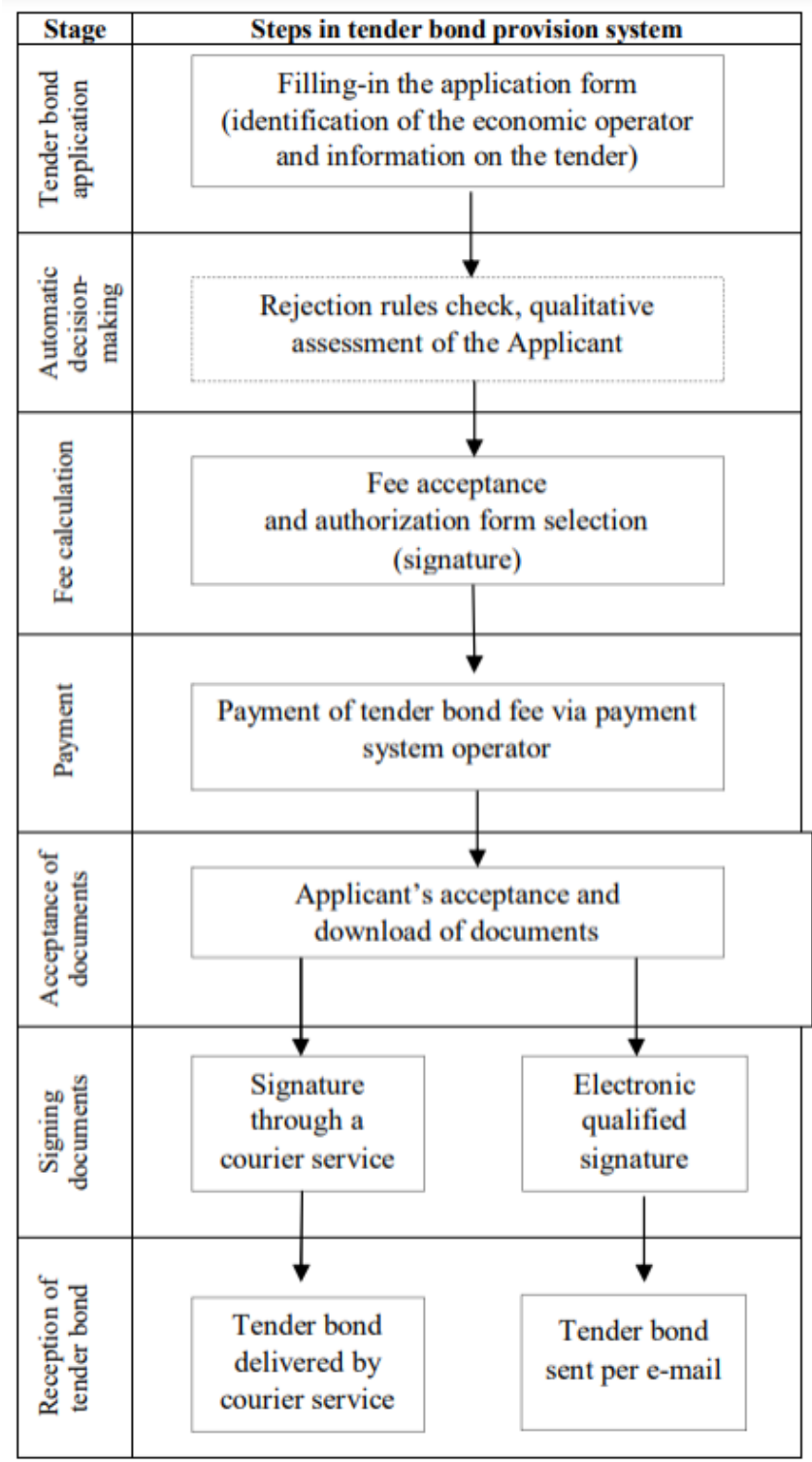

Figure 1. The application process diagram for issuing a tender bond Source: the author's own study. 
Table 3. Qualification rules for economic operators applying for tender bonds

\begin{tabular}{|c|c|c|c|}
\hline No. & Rule & Quantifier & Data sources \\
\hline 1. & $\begin{array}{l}\text { Active business activity } \\
\text { (NIP - Tax Identification Number) }\end{array}$ & $=$ & $\begin{array}{l}\text { GUS (Statistics } \\
\text { Poland) }\end{array}$ \\
\hline 2. & Duration of business activity & $\leq 12$ months & GUS \\
\hline 3. & $\begin{array}{l}\text { Economic operator's line of business } \\
\text { (potential sectorial exclusions) }\end{array}$ & $=$ & GUS \\
\hline 4. & $\begin{array}{l}\text { Number and scope of public procurement } \\
\text { procedure }\end{array}$ & $=$ & $\begin{array}{l}\text { Public Procurement } \\
\text { Bulletin }\end{array}$ \\
\hline 5. & Credit arrears & $\geq$ PLN 500 & \multirow{4}{*}{$\begin{array}{l}\text { Business Information } \\
\text { Bureau }^{20}\end{array}$} \\
\hline 6. & Number of negative credit data & $\geq 2$ & \\
\hline 7. & Number of days of late credit payments & $\geq 90$ & \\
\hline 8. & Total amount of uncontested obligations & $\geq$ PLN 500 & \\
\hline 9. & Current risk class of the credit guarantee fund & $\geq$ risk class & \multirow{3}{*}{ The fund's database } \\
\hline 10. & Value of outstanding fees for sureties issued & $\begin{array}{c}\geq \text { PLN 200, } 91 \\
\text { days }\end{array}$ & \\
\hline 11. & $\begin{array}{l}\text { Surety payment in connection with the } \\
\text { economic operator }\end{array}$ & $=$ & \\
\hline 12. & $\begin{array}{l}\text { The amount applied for exceeds the current } \\
\text { limit }\end{array}$ & \multirow{3}{*}{$=$} & \multirow{3}{*}{$\begin{array}{l}\text { Online sale system for } \\
\text { tender bonds }\end{array}$} \\
\hline 13. & $\begin{array}{l}\text { Acceptance of mandatory representations and } \\
\text { consents }\end{array}$ & & \\
\hline 14. & Acceptance of tender bond provision terms & & \\
\hline
\end{tabular}

Source: the author's own study.

The qualification rules for economic operators which allow them to file the application for a tender bond are primarily aimed at verifying the basic parameters relating to the economic operator, as, for instance, its economic activity status (is it active?), the line of business, etc. From the formal point of view, it is essential to check whether the procedure for awarding a public contract connected to the tender bond in question has been registered in the public procurement database run by Public Procurement Agency. In addition, what also needs to be investigated is the negative information pertaining to such issues as the economic operators'

${ }^{20}$ Business Information Bereau operating under the Act of 9 April 2010 on the availability and sharing of business information (OJ No 81, item 530), making the information, collected by Biuro Informacji Gospodarczej S.A. (Business Information Bureau, JSC) and the Polish Banks Association, on economic operators covering the information on outstanding payments to banks and other institutions authorized to provide credit or on no such debts available (e.g. Biuro Informacji Gospodarczej BIG InfoMonitor Sp. z o.o., Krajowego Rejestru Długów Biura Informacji Gospodarczej S.A.). 
credit history (e.g. loan arrears, the volume of negative credit information, the number of days of delay in repayment of loans, etc.). The preliminary analysis can also refer to the data available in the databases of the credit guarantee fund providing the tender bond (e.g. current risk class of the economic operator which is the fund's client, the potential value of payment arrears for sureties provided to the economic operator, whether a surety has already been paid to the economic operator applying for a tender bond). Table 3 shows examples of the qualification rules for economic operators applying for a tender bond.

The verification of the qualification rules should be conducted sequentially, i.e. the rules are being checked one after the other; if any of the rejection rules in sequence is activated, the verification process is aborted and the tender bond application is rejected.

As a complementary measure to the qualification rules applied in the verification of economic operators applying for a tender bond, one could also use the application assessment based on qualitative parameters. Under the simplified process of the tender bond online sale, the evaluation of the economic operator's financial data is rather not envisioned.

The qualitative evaluation should primarily encompass the following elements:

a) the past history of cooperation with the credit guarantee fund, if applicable,

b) duration of the economic operator's business,

c) risk involved in the relevant line of business,

d) the economic operator's experience in public procurement participation,

e) the status of the latest active surety issued by the fund,

f) arrears in loan payments,

g) others.

An example of the qualitative evaluation scope applied in the tender bond applications filed by economic operators is presented in Table 4. Points and weights should be allocated to individual elements making up the qualitative evaluation of economic operators depending on the impact a given parameter has on the risk involved in the provision of the tender bond. The point-based intervals set by the expert method will identify different risk groups within which individual economic operators will fall. The risk group can, in turn, determine the maximum amount of the tender bond, the period for which it will be provided or the fee charged by the fund. 
Table 4. An example of the qualitative assessment scope for an economic operator applying for a tender bond

\begin{tabular}{|c|c|c|c|c|}
\hline No. & $\begin{array}{l}\text { Qualitative assessment } \\
\text { elements }\end{array}$ & \multicolumn{2}{|c|}{ Parameter description } & $\begin{array}{l}\text { Impact on } \\
\text { assessment } \\
\text { (weight) } \\
\end{array}$ \\
\hline 1. & $\begin{array}{l}\text { Cooperation with credit } \\
\text { guarantee fund }\end{array}$ & \multicolumn{2}{|c|}{$\begin{array}{l}\text { verification whether or not the economic } \\
\text { operator has been the fund's client }\end{array}$} & + \\
\hline \multirow{2}{*}{2.} & \multirow{2}{*}{ Duration of business activity } & \multicolumn{2}{|l|}{ above 37 months } & + \\
\hline & & \multicolumn{2}{|c|}{ between 13 and 36 months } & ++ \\
\hline \multirow{5}{*}{3.} & \multirow{5}{*}{ Line of business } & \multirow{5}{*}{$\begin{array}{l}\text { Statistical } \\
\text { classification of } \\
\text { economic activity in } \\
\text { Poland }\end{array}$} & low & ++ \\
\hline & & & moderate & + \\
\hline & & & elevated & - \\
\hline & & & high & -- \\
\hline & & & very high & --- \\
\hline \multirow{9}{*}{4.} & \multirow{9}{*}{ Tendering experience } & \multirow{3}{*}{$\begin{array}{l}\text { number of tenders in } \\
\text { which the economic } \\
\text { operator participated } \\
\text { over the last years }\end{array}$} & between 0 and 5 & + \\
\hline & & & between 6 and 15 & ++ \\
\hline & & & above 15 & +++ \\
\hline & & \multirow{3}{*}{$\begin{array}{l}\text { number of tenders } \\
\text { won over the last } \\
\text { three years }\end{array}$} & between 0 and 2 & + \\
\hline & & & between 3 and 9 & ++ \\
\hline & & & above 10 & +++ \\
\hline & & \multirow{3}{*}{$\begin{array}{l}\text { estimate value of } \\
\text { tenders won over the } \\
\text { last three years }\end{array}$} & $\begin{array}{l}\text { between PLN } \\
0 \text { and } 100 \mathrm{k} \\
\end{array}$ & + \\
\hline & & & \begin{tabular}{|l|} 
above PLN $100 \mathrm{k}$ \\
up to $300 \mathrm{k}$ \\
\end{tabular} & ++ \\
\hline & & & above PLN $300 \mathrm{k}$ & +++ \\
\hline \multirow{5}{*}{5.} & \multirow{5}{*}{$\begin{array}{l}\text { Status of the last active surety } \\
\text { provided by the fund }\end{array}$} & \multicolumn{2}{|l|}{ performing } & ++ \\
\hline & & \multicolumn{2}{|l|}{ on watch -list } & + \\
\hline & & \multicolumn{2}{|l|}{ substandard } & - \\
\hline & & \multicolumn{2}{|l|}{ doubtful } & -- \\
\hline & & \multicolumn{2}{|l|}{ loss } & --- \\
\hline 6. & Loan payment arrears & \multicolumn{2}{|c|}{$\begin{array}{l}\text { one and more exceeding PLN } 200 \text { and } 30 \\
\text { days }\end{array}$} & -- \\
\hline 7. & $\begin{array}{l}\text { Creating an account in the } \\
\text { system of tender bond } \\
\text { provision }\end{array}$ & \multicolumn{2}{|c|}{ applicant has agreed to marketing } & + \\
\hline
\end{tabular}

Key: + sign stands for a positive impact on the qualitative assessment, - sign denotes a negative impact on the qualitative assessment, where + or - denote a moderate impact, $++/--$ a big impact, $+++/---$ a very big impact

Source: the author's own study. 
The total number of points awarded to an entrepreneur applying for a tender bond is calculated as the sum of the product of the number of points allocated to a particular parameter and its weight.

$$
P_{p w}=\sum_{i=1}^{n} P P_{n} \times W_{n}
$$

where:

$\mathrm{P}_{\mathrm{pw}}$ - denotes the sum of points awarded to the undertaking applying for surety, $\mathrm{PP}_{\mathrm{n}}$ - denotes the number of points allocated to an $\mathrm{n}$-th parameter of the qualitative assessment, $\mathrm{W}_{\mathrm{n}}$ - denotes the weight of an $\mathrm{n}$-th parameter.

The credit guarantee funds can develop their own methods of applicant assessment drawing on their own experience and analysis of the data collected.

The online process implementation results are expected to contribute to enhance economic operators' access to tender bonds and simplify the entire procedure. Funds for credit guarantees will benefit from the presented concept of a procedure for tender bond application by increasing sales of sureties as well as reduce risks involved in the non-monetary forms of the deposit securing public procurement procedures.

What further appears to be of key importance for the funds is to conduct educational activities addressing directly economic operators with a view of raising their awareness as to the alternatives of paying the deposit other than in cash.

\section{CONCLUSIONS}

As the data presented by the credit guarantee funds show, there has been a 26 consistent increase in the volume and value of tender bonds provided by an ever growing number of credit guarantee funds. For many funds tender bonds account for the largest share in their guarantee portfolios, thus leading to a reorientation of their operations. As the risk involved in tender bonds is relatively low (a short term of their validity, a limited tender bond amount), the funds are interested in increasing the sale of these sureties. In order to make the funds' tender bond offer more attractive and to convince economic operators to choose this form of deposit payment in tender procedures, one needs to continuously improve the process of issuing bonds. The funds should seek to develop and implement a system for selling tender bonds online. The information technology tool to be used by the credit guarantee funds will enable the sale process, which should proceed swiftly, 
to be simplified and shortened substantially (in terms of time needed, it should be comparable to making a transfer to the contracting authority's bank account). The system should adopt a very simple assessment of economic operators applying for tender bonds and automate possibly all operations involved in the tender bond provision, including an electronic form of the statement confirming provision of a tender bond bearing a qualified signature. This will allow the process to be accelerated, possibly leading to a greater interest among economic operators in this form of securing the public procurement procedure. The guarantee funds which decide to implement the system of selling tender bonds online will be able to become market leaders thus increasing their revenues generated by tender bond sale. Making the non-monetary form of deposit payment in a tender procedure more popular may also prove to be positive for limiting the negative consequences brought about by temporary liquidity problems which economic operators have to face.

\section{REFERENCES}

Fundusze poręczeniowe w nowej sytuacji rynkowej. Adaptacja, transformacja oferty produktowej, Bank Gospodarstwa Krajowego, https://ksfp.org.pl/publikacje/raporty/ [Accessed: 1.06.2020].

Gajewski, M., Kubajek, R. and Szczucki, J. (2019). Rynek lokalnych i regionalnych funduszy poręczeniowych $w$ Polsce w 2018 r. Warszawa: Krajowe Stowarzyszenie Funduszy Poręczeniowych, PAG Uniconsult.

KGP, https://grupaporeczeniowa.pl/index.php/produkty-finansowe/115-poreczenia-wadialne [Accessed 4.05.2020].

Mazurek, G. (2018). Wadialna gwarancja ubezpieczeniowa. Przetargi Publiczne, 1.

Packo, A. (2016). Zwrot i zatrzymanie wadium. Problemy praktyczne w świetle orzecznictwa KIO. Wrocław: Presscom Sp. z o.o.

Panasiuk, A. (2013). System zamówień publicznych zarys wyktadu. Warszawa: Public Procurement Legal Publisher.

Pieróg, J. (2019). Prawo zamówień publicznych. Komentarz. Warszawa: Wydawnictwo C.H. Beck. Pieprzyca, P. (2018). Gwarancja ubezpieczeniowa. Przetargi Publiczne, 2.

Puchacz, K. (2010). Kontrola zamówień publicznych. Wrocław: Presscom Sp. z o.o.

Raporty o stanie funduszy poręczeń kredytowych w Polsce: 2005, 2006, 2007, 2008, 2009, 2010, 2011, 2012, 2013, 2014, 2015, 2016, 2017, Krajowe Stowarzyszenie Funduszy Poręczeniowych, PAG Uniconsult.

Legal acts:

Rozporządzenie Ministra Rozwoju z dnia 26 lipca 2016 r. w sprawie rodzajów dokumentów, jakich może żądać zamawiający od wykonawcy w postępowaniu o udzielenie zamówienia, Dz.U. 2016, poz. 1126.

Ustawa z dnia 29 stycznia 2004 r. Prawo zamówień publicznych, Dz.U. 2019, poz. 1843.

Ustawa z dnia 11 września 2019 r. Prawo zamówień publicznych, Dz.U. 2019, poz. 2019.

Ustawa z dnia 23 kwietnia 1963 r. - Kodeks Cywilny, Dz.U. 2019, poz. 1145; Dz.U. 2019, poz. 1495.

Ustawa z dnia 18 lipca 2002 r. o świadczeniu usług drogą elektroniczną, Dz.U. 2019, poz. 123, 730.

Ustawa z dnia 29 sierpnia 1997 r. - Prawo bankowe, Dz.U. 2019, poz. 2357.

Ustawa z dnia 9 listopada 2000 r. o utworzeniu Polskiej Agencji Rozwoju Przedsiębiorczości, Dz.U. 2019, poz. 310, 836, 1572. 


\section{PORĘCZENIA WADIALNE W PRZETARGACH PUBLICZNYCH: UWARUNKOWANIA, PROCEDURY, IMPLIKACJE DLA FUNDUSZY PORĘCZEŃ KREDYTOWYCH}

\section{Streszczenie}

Celem artykułu jest przedstawienia zarysu nowej procedury, umożliwiającej zwiększenie dostępu przedsiębiorców do poręczeń wadialnych udzielanych przez fundusze poręczeń kredytowych, które stanowią jedną z dostępnych niepieniężnych form wnoszenia zabezpieczenia $\mathrm{w}$ postępowania o udzielenie zamówienia publicznego $w$ postaci wadium.

Metodologia wykorzystana do przedstawienia tematu oraz realizacji celu artykułu, opiera się głównie na opinii oraz zawodowym doświadczeniu autora.

Rezultatem przeprowadzonej analizy jest zwrócenie uwagi, że poręczenia wadialne, pomimo właściwego usankcjonowania w polskim systemie prawnym, są nadal w marginalny sposób wykorzystywany przez przedsiębiorców ubiegających się o udzielnie zamówienia publicznego. Jednocześnie większość funduszy poręczeń kredytowych koncentruje się na udzielaniu tego typu poręczeń, co w konsekwencji powoduje malejący udział poręczeń kredytowych oraz zmianę profilu działalności funduszy poręczeniowych. Dalsze zwiększania sprzedaży poręczeń wadialnych, wymaga od funduszy poręczeniowych modyfikacji istniejących procedur w celu zwiększenia popularności poręczeń wadialnych wśród przedsiębiorców.

Słowa kluczowe: fundusz poręczeń kredytowych, poręczenie, wadium, zamówienia publiczne, mikro, małe i średnie przedsiębiorstwa. 